\title{
"A False Idea of Economy": Costs, Counties, and the Origins of the California Correctional System
}

W. David Ball

Santa Clara University, wdball@scu.edu

Follow this and additional works at: https://digitalcommons.law.scu.edu/facpubs

Part of the Law Commons

\section{Automated Citation}

W. David Ball, "A False Idea of Economy": Costs, Counties, and the Origins of the California Correctional System, 664 ANn. AM. ACAD. Poli. Sci. 26 (2016),

Available at: https://digitalcommons.law.scu.edu/facpubs/967 
Realignment in California comes at a time when the state's prison system is expensive and overcrowded; the response has been to reevaluate and reconfigure the way counties use state prisons. Based on an original historical analysis of state archival records from the late nineteenth and early twentieth centuries, as a well as a review of secondary historical accounts of California's prison system, I show that similar problems and policies were present at the state's founding: issues of

"A False Idea of Economy": Costs, Counties, and the Origins of the California Correctional System

$B y$

W. DAVID BALL expense, overcrowding, and the county-state relationship help to explain the origins, size, and shape of the California prison system. California's lack of money first drove it to try to house prisoners on the cheap, starting when it made county jails the state prison system by fiat, continuing through a decade of privatization and convict lease arrangements in San Quentin, and concluding with a state-administered system partly funded by prison labor. By the time the value of prison labor atrophied and the true costs of a nonremunerative prison system revealed itself, the state was locked into fiscal and administrative responsibility for prisoners. Along the way, however, state and local governments sought to pass carceral responsibilities - and their attendant expenses-from one level of government to another in a manner that resembles today's battles over Realignment.

Keywords: prisons; California; correctional free lunch; realignment

Tn 2011, California's prisons were deemed Lunconstitutionally overcrowded, and the state was ordered to reduce its prison

W. David Ball is an associate professor at Santa Clara School of Law. His research has been published in the Columbia Law Review, the Yale Law and Policy Review, the Stanford Law and Policy Review, and the American Journal of Criminal Law, among others. He currently serves as cochair of the American Bar Association's Corrections Committee.

NOTE: The author wishes to thank Ellen Platt, Kendra Livingston, and Riana Talaugon for their research assistance and Kyle Graham, Brad Joondeph, Charis Kubrin, Brian Love, Michelle Oberman, Carroll Seron, David Sloss, Anjuli Verma, and Bob Weisberg for their comments on earlier drafts of this article.

Correspondence:wball@scu.edu

DOI: $10.1177 / 0002716215601844$ 
population (Brown v. Plata 2011). That same year, California embarked on a policy of criminal justice Realignment-a reconfiguration of county- and statelevel carceral responsibilities. Realignment changed the location where certain crimes are punished: nonserious, nonviolent, nonsex offenses previously eligible for state prison are now served locally in "county jail prison" (Ball and Weisberg 2014). County jail prisons are a legal construction: prisoners are physically in county jails, but they are constructively serving state prison time. Given the budget crisis at the state level, county jail prison has one more important feature: counties pay for it, while the state continues to pay for sentences served in state prison.

This article examines the first 50 years of California statehood and reveals that the current attempt to address prison overcrowding through a realignment of state and local responsibilities is not the first. Based on an original historical analysis of state archival records from the late nineteenth and early twentieth centuries, as a well as a review of secondary historical accounts of California's prison system, I explore how issues of expense, overcrowding, and the countystate relationship have been with the state from the very beginning. Indeed, these factors help to explain the origins, size, and shape of the California prison system. At statehood, California had almost no carceral infrastructure; that which it had was entirely local. The state prison system started off as a legal fiction, when, by legislative fiat, the state prison was deemed to consist of the state's county jails. Realignment's notion of "county jail prison" is thus, in a very real sense, as old as the state itself.

Three prior articles have examined the financial incentives affecting the size and shape of prisons, using, as a jumping-off point, what Frank Zimring and Gordon Hawkins called "the correctional free lunch"-a hypothesis that local actors are more likely to use carceral resources that the state pays for (e.g., state prisons) rather than local resources paid for locally (e.g., county jails) (Zimring and Hawkins 1991). One article explored the ways in which contemporary California state incarceration rates provide evidence of the correctional free lunch (Ball 2012); another explored what policy prescriptions might address localities' misaligned incentives (Ball 2014a).

This article builds most on the historical, comparative, and theoretical analysis presented in a third article (Ball 2014b) and looks at the financial incentives of localities as a possible source of state prison overcrowding in the first 50 years of California statehood. Ball (2014b) asked about the origin of state prisons, seeking to understand why states would ever have agreed to pay for prisons when local officials decide who goes there. Looking primarily at economic factors, the article argued that the rise of the American state prison in the nineteenth century was the result of a confluence of two factors: prison reformers who wanted the classification and professionalism of statewide institutions and state governments seeking the economic benefits of prison labor. Once prison labor failed to deliver income, the state was left with the responsibility for state prisoners and the economic costs that came with them-the conditions precedent for a correctional free lunch.

This article is a case study of the economic incentives behind state and local control of incarceration in the first 50 years of California statehood. As was true 
in other states, California was only too glad to establish prisons when it believed prisoners, through their labor, would be a source of profits, not costs. As the promise of profits waned, however, state officials sought to ration access to prisons by limiting the financial incentives local governments had for using themand even, in some cases, sought to save money by shuttering the state prison and replacing it entirely with local alternatives.

The lesson from this history is that state and local governments in California have long struggled over which level of government should be responsible for incarceration, and such disputes have often had economic dimensions. In the early years, as today, California had problems with overcrowding, budget constraints, and high levels of recidivism, and the public was unwilling to invest its money to improve the system. At the end of the first 50 years of California incarceration, Governor George Pardee, citing a legislative committee report, decried this penny-wise, pound-foolish approach, lamenting that the prisons were "schools of vice and universities of crime" from which young men graduated "fully equipped enemies of society." Pardee assigned "responsibility for this great wrong" not to the prison administrators but to the people of California, "who have followed a false idea of economy, and, steeped in neglect of public affairs, have failed to provide means for the proper conduct of these institutions" (Pardee 1905, 29).

\section{Costs, Counties, Crowding, and the Birth of San Quentin}

Before California became a state in 1850 , it did not have much in the way of colonial governmental structures to build on. It was not like correctional vanguards Pennsylvania or New York, states with much better established forms of municipal and colonial government and much more stable populations. California had no urban centers to speak of before the 1849 Gold Rush, and the Spanish (and then Mexican) criminal justice systems were based on a nonadversarial civil system where punishments were largely noncarceral (a mixture of banishment, corporal, and capital punishment). The alcalde, a mixture of judge and mayor, "was relied upon for the investigation of crimes, for the trials, and for the sentencing of offenders" (Langum 1987, 56). Nonlawyers represented defendants in criminal cases, since "legal expertise was not readily available" (Langum 1987, 64). There was no large-scale imprisonment of any kind, even at the local level. What jails there were served only as "temporary holding cells for defendants awaiting sentences or, at best, as places of confinement for short sentences while a defendant served a month or two in labor at local public works," because jails "presented absolutely miserable conditions and because they provided frequent opportunity for escape" (Langum 1987, 83). During California's brief spell as a territory administered by the U.S. military, "control of the criminal justice apparatus in California was tenuous" (Mullen 1989, 41).

When gold was discovered in 1849, California's population exploded from about twelve thousand to one hundred thousand by the end of the year (Mullen $1989,47)$. The state was not ready for the demands placed on it. There was no 
state prison, and, for the two years following the Gold Rush, there was not "any central authority having control of prisoners" (Ford 1910, 11-13). Prior to 1849 , there were only six jails in the territory: San Francisco, San Jose, Monterey, Santa Barbara, Los Angeles, and San Diego (Wilkins 2005, 8). Just two of them took offenders from other parts of the state. The Sacramento jail-the brig "La Grange"-held prisoners from gold camps that had no secure jails, in addition to local offenders (Boessenecker 1999, 274). San Francisco also took sentenced felons from the mining regions (Boessenecker 1999, 273).

The state did not move to set up its own authority over prisoners at its first legislative session, choosing instead, at the end of its new penal code, to deem the county jails the state prison (State of California 1850, 247). Section 144 of Chapter 99, "An Act Concerning Crimes and Punishments," reads, in full, "Until a State Prison is provided, the County Jail of each county shall be deemed the State Prison." All state crimes were thus originally punished in county jail state prisons.

By not providing a prison, the state was aware that it was saving money. The Prison Report of 1852 , despite advocating for a state facility, reported that the state was saving $\$ 70,000$ a year by not having one. In 1851, during his state of the state address, Governor Burnett said that counties were footing the incarceration bill on the state's behalf but that "the expense of detaining prisoners from one term to another is exceedingly oppressive upon some of the counties" and that "the administration of the criminal laws of the State, especially in the mining counties" had been rendered "almost wholly impracticable" (Burnett 1851, 799). The state had, in short, delegated a responsibility to counties that the counties were too overwhelmed (and too financially strapped) to carry out.

The Prison Report of 1852 made clear that the state had to move to provide more secure punishment for its criminals, observing that "the want of proper places of incarceration" was breeding vigilantism (Committee on State Prison $1852,245)$. There was no good place to put convicts: county jails were insufficient, "generally temporary buildings, inadequately secure, and sometimes not properly guarded," meaning that "the great majority of convicts" escaped (Committee on State Prison 1852, 245). The need for a state prison was both "immediate" and "indispensible to the public safety" (Committee on State Prison $1852,246)$.

Still, the notion of a state prison was far off. The initial postcounty move was, in some ways, neither toward the state nor toward a prison. The state initially transferred prisoners to the legal custody of two private lessees: there was no permanent prison building until 1854, and even that was built on private initiative (albeit with the labor of state prisoners) (Wilkins 2005, 54). The history of the first 10 years of San Quentin has already received several excellent treatments that I will not duplicate here (see, e.g., Bookspan 1991; Ford 1910; Lamott 1961; McAfee 1990; McKanna 1987; Wilkins 2005). I will provide a brief summary that highlights the chaos (and pathos) of those early days.

In April 1851, California leased its prisoners to James Estell and a partner, with the lessees paying the state to receive the convicts and use their labor (State of California 1851, 427). According to the terms of the lease, the state was to be 
"free of any expense" relating to the prisoners (State of California 1851, 427). Prisoners were put on a ship, the Waban, which immediately went beyond its fifty-person capacity (Ford 1910, 13-15). It dropped anchor at the present site of San Quentin on Bastille Day, 1852 (Duffy 1950, 88), and in May 1853, the state agreed to build a prison there (State of California 1853, 156-57). The first permanent structure of the prison itself, the Stones, was built on Estell's private initiative and completed in 1854. It remained in use until 1959 (Lamott 1961, 28). It was soon evident that San Quentin was a poor location for a prison, and several legislative committees recommended shutting it down as early as 1857 (Committee on State Prison 1857; Select Committee 1857; Joint Committee on State Prison Affairs 1858), a proposal repeated at the end of the nineteenth century by two governors (Markham 1895; Budd 1895; Budd 1897) and the State Board of Prison Directors (1896).

After a series of scandals involving escapes, drunkenness, and bad bookkeeping, in 1855 the state broke its lease and took over management of the prisoners, only to burn through almost half a million dollars (about 50 percent of the state budget) in 11 months. It then made a new contract with the scandal-plagued Estell, only this time it now paid him $\$ 10,000$ a month to take the prisoners. This was expensive, but "California was eager to transfer the financial burden back to someone else, even to Estell" (Bookspan 1991, 16). During his second contract, Estell brought on another partner, another scandal ensued, and the state once again took over operation of the prison (in 1858) and was sued by Estell for breach of contract. The governor was found personally liable, and the state eventually settled the dispute for $\$ 275,000$ (Bookspan 1991, 19).

Fiscal concerns thus dominated the development of the state prison at San Quentin. California decided to rely on privatization due to the state's "deplorable financial condition" (McAfee 1990, 235-36), but it paid dearly in the end for what Governor Downey would describe as a "ruinous" contract (Downey 1861, 30). San Quentin was at its most expensive, however, when the state took over the prison from Estell in 1855. It spent \$475,413 in 11 months (Ford 1910, 17), which, in the seven months of the fiscal year 1855-1856, was almost half of the state's estimated expenses (Lamott 1961, 41). This was during a time when the state defaulted on interest payments (in 1854 and 1856) and was racking up debts of $\$ 4$ million, far beyond the constitutional ceiling of $\$ 300,000$ (Tuthill 1866, 525-26). All told, as the State Controller reported in 1860, the total expenses since 1852 for the keeping of state convicts was $\$ 1.5$ million (Brooks 1861). Once the second lease expired at the end of the 1850s, the state was again faced with how to manage the expense of its prisoners.

The answer was to contract out prison labor, a system that had been used to great effect in the East (McLennan 2008). Though it may be hard for the contemporary reader to imagine, incarceration was not always seen as a cost center. On the contrary, prison labor, whether through a lease or contract system, was seen as a way to add income to governmental budgets. States assumed control over prisoners during the heyday of prison labor. Once prison labor was no longer economically valuable, however, states were nevertheless left with substantial 
administrative and fiscal responsibilities (Ball 2014b). The correctional free lunch, then, could occur only after the demise of prison labor, resulting in the need to realign county and state incentives.

California was initially confident that prison labor would make the prison selfsupporting or profitable. An 1857 report by the Committee on the State Prison Contract concluded that the problem was management, and that, with a mere $\$ 6,000$ capital investment, the prison could be made "self-supporting at least, if it does not yield large profits." In 1875, Governor Irwin reported that if the state found more work for prisoners, "the prison would be very nearly self-supporting" (Irwin 1875, 28). Reports of the Joint Committee in 1874 (pp. 10-11) and the State Board of Prison Directors in 1882 (p. 5) said much the same. There were, of course, other reasons to support prison labor-it reformed prisoners, as the warden of San Quentin noted (State Board of Prison Directors 1880).

But prison labor never delivered on the promise of profits. Part of the reason was physical - the inadequate site at San Quentin meant that there was not enough room for workshops (Joint Committee 1872, 10). Part of the reason was also political - the free labor movement opposed prison labor's depressing effect on wages, particularly since the main site of manufacturing in California, San Francisco, was so close to the prison. The labor-dominated California constitutional convention of 1878-1879 prohibited the contract prison labor system through Article X (Eaves 1910, 36). After the contract system was outlawed, it continued to exist "under a different name" (Enos 1887, 125), but it was finally restricted to competing only in two industries: jute bags in San Quentin and stone in Folsom (Eaves 1910, 366). The role of prison labor was thus somewhat paradoxical: by statute, all able-bodied prisoners were required to work, but what they could do was deeply restricted (Wythe 1909, 99). The state was allowed to use prison labor for its own use, however, and this undoubtedly made the erection of prisons cheaper (State Board of Prison Directors 1880, 12). The state paid for the land at Folsom prison "in convict labor, rated at fifty cents per diem" (Joint Committee 1872, Appendix p. 4) and built it with prison labor.

The successful campaign to eliminate prison labor was situated within more racialized labor disputes: the white labor movement did not object to prison labor when it dovetailed with its anti-Chinese sentiment. An early circular published by the Mechanics' State Council in 1874 explicitly recommended that the prison system "compete with Chinese labor" and found that this change would yield a profit of almost a million dollars (pp. 3-5). That same year, the state prison report discussed the impact of prison labor and Chinese labor on the free white market (see, e.g., testimony by one saddle maker linking the fact that he was "forced" into employing Chinese labor because he "was losing money and could not afford to sell for the prices the State Prison contractors sell their goods" [Joint Committee 1874, 49]). The same labor-dominated California constitutional convention that prohibited contract prison labor was much better known for several anti-Chinese provisions, including one, Article XIX, that banned all public hiring of Chinese people "except in punishment for crime" (Wythe 1909, 89). Even the reason for selecting jute bags as San Quentin's industry of choice was racially motivated. Before San Quentin got into the business, the only California manufacturer of jute bags employed Chinese workers (Lamott 1961, 132). 


\section{Did Financial Free Riding Cause Crowded Prisons?}

The correctional free lunch was not born until the idea of profitable prisons died. After all, if states believed they could make money from prisoners, state custody would be offset by control of an economic asset. There is ample evidence that the size and shape of the state and local responsibility for incarceration was heavily influenced by financial considerations. Because counties had, if anything, even less money than the state-Governor Downey reported in 1861 that the counties had about $\$ 10$ million in debt (Downey 1861, 31) —were counties inclined to use "free" state prisons to deal with criminal justice rather than spending their own money to punish offenders locally; and if so, did this contribute to state prison overcrowding?

At the end of the first decade of the California prison system, at least some state officials thought so. In 1858, the Joint Committee on State Prison Affairs proposed something radical—something similar to Realignment. For all sentences under two years, the Committee recommended incarceration at the county level, with costs to be offset by road work. By requiring that "all offenders be punished in the counties where convicted, unless for offences requiring two years in the state prison," and by permitting counties to work offenders on "the public roads and streets in their respective counties," the state would not only incur "less expense than is now incurred in sending them to the penitentiary" but also "check the further increase of numbers at the state prison" (Joint Committee on State Prison Affairs 1858, 9-10). In other words, the committee thought cost avoidance was driving county commitments and that these commitments led to overcrowding at the state prison.

Governor Downey repeated this proposal three years later in an 1861 address to the state legislature. After discussing the cost of prisons and arguing that prison labor should pay for prison costs, he said that prison should only be for those serving long terms. Downey was more explicit than the State Prison Affairs Committee in suggesting that counties were simply trying to pass carceral costs on to the state: "Convicts are now sent for terms as short as three months, and it would appear as though they are sent for the purpose of getting rid of them as county charges" (p. 33).

Ultimately, we do not have enough data about crime to determine whether increases in the prison population were just a natural result of increased criminal activity or increased cost passing. One thing is certainly clear, however: San Quentin was overcrowded from the beginning. In 1858, the Committee on the State Prison offered this sobering depiction of overcrowding in San Quentin, in a scene that is only too reminiscent of the photographs in Brown v. Plata (2011, Appendix B).

In the "long room," so-called ... are turned loose, like so many brute animals in a corral, to stay and sleep, the young, middle-aged and old . . . thus rendering reform and reformation seemingly impossible. . . . The manner of stowing away such a number in so small a space is accomplished by placing a row of standee bunks close to each other on each side of the room, with their heads to the wall, leaving an open space through the middle of the room, the bunks being one above another, and into which the prisoners crawl from the end, the open space being so small that before any take their bunks it is with a good deal of difficulty you can make your way through the crowd. (Joint Committee on State Prison Affairs 1858, 6) 
Overcrowding was relieved in the very early days primarily through escapes: almost a quarter of the prisoners escaped in the first 10 years of the prison (Ford 1910, 26). Escape was, of course, not a politically viable means of controlling the population, and it, "more than any other factor, undermined California's willingness to experiment with privatization" (McAfee 1987, 862).

After the expiration of the lease in 1860, the prison was at almost twice its capacity (Weller, 1860, 57); in 1874, some prisoners had barely 20 percent of the cubic footage required (Joint Committee 1874, 4). After Folsom took its first prisoners, San Quentin remained overcrowded: there were 1,309 prisoners in 703 cells, "render[ing] classification impossible," mixing the "younger and less criminal class" with the "vilest and most depraved elements of criminal life," destroying the former's good qualities "without in the slightest degree redeeming the utterly vicious" (State Board 1880, 11). An early historian of the California prison system concluded in 1910 that "there has never been a time in the history of the prisons of California when the cell room was sufficient to accommodate the prisoners in separate cells" (Ford 1910, 25).

One response to overcrowding was to call for changes to sentences. Several governors addressed the legislature and lobbied for reduced sentences to reduce the prison population. Weller $(1858 \mathrm{~b}, 307)$ argued on behalf of lower sentences for first timers, a position later echoed by Markham (1893, 44-45) and Budd $(1897,39)$. Governors, though, needed the legislature's assistance to make this happen, and it was not readily forthcoming. A far more effective means of population control was entirely in the governors' hands: prisoner releases. Even serious offenders were pardoned: using data from McKanna (1989), California governors pardoned 28.2 percent of homicide offenders sentenced to state prison from 1850 to 1900 .

Governors themselves, though, criticized pardons as being too arbitrary (Messinger et al. 1985, 75), and pardons were gradually replaced by parole (Messinger et al. 1985, 91) and good time credits. Both were linked to labor. Simon (1993) situates parole within the wider context of control of the poor and working class; applicants for parole initially had to secure a job before release (Messinger et al. 1985, 85). By the early twentieth century, "employment was virtually the entire [parole] program" (Simon 1993, 49).

These policies were often justified on the grounds that they saved money. The Prison Report of 1892, for example, argued that appointing a more active "State Agent" to "look after discharged convicts" would "save the State a sum many times greater than the cost, and that it would be an economical as well as a reformatory measure" (State Board 1892, 7). The Charities Report of 1906 proposed what can best be described as a form of what is now called Post-Release Community Supervision (PRCS), whereby "the probation officer in each county [would] look after prisoners paroled to his county" (California State Board 1906, 41). Crucially, though, this would "not be expensive to the State, as in most of the counties the probation officers serve without pay." Thus, the cost savings to the state would be amplified by shifting work, but not compensation, to the counties. 


\section{Contrasting crime and punishment in the early statehood era}

State prisons under Realignment today are reserved for, inter alia, "serious" offenses. Property offenders are, generally, punished locally, whether in county jail or county jail prison. This conception of "serious" crimes and where they should be punished was turned on its head in the early years of statehood. Back then, the state prisons were mostly full of property offenders. In the Joint Committee on State Prison Affairs Report of 1858, one learns that of a total of 1,297 prisoners sent to San Quentin from 1851 to 1858, more than half (721) were there for grand larceny, as opposed to 106 for assault with intent to kill, 90 for burglary, 86 for manslaughter, and 65 for assault. This trend continued, with McKanna $(1985,480)$ reporting that, from 1850 to 1880 , grand larceny and burglary alone were responsible for more than half of all prison admissions across Anglo, Chinese, and Hispanic populations. Ford $(1910,48)$ reported that more than 80 percent of offenders sentenced to prison from 1880 to 1910 were property offenders.

Unlike today, most nineteenth-century prison sentences were also relatively short. Reports from 1852 show that of the forty-four prisoners in custody, "twentyone were serving sentences of only one or two years," and just seven were serving more than five years (Lamott 1961, 31). McKanna $(1985,480)$ shows that nearly half of Anglo and Hispanic prisoners and more than 40 percent of Chinese prisoners were serving sentences of one to two years (1850-1880) and that almost 80 percent of all groups were serving five years or less. The majority (60 percent) of sentences from 1880 to 1910 were for less than five years, and 80 percent were 10 years or less (Ford 1910, 49). It is striking, however, that 12.5 percent of life sentences were for property offenses (Ford 1910, 52).

On the local level, punishments ranged from the trivial to the ultimate. The death penalty, for example, was administered locally until 1891 (Duffy 1950, 16), but the only two detailed studies (of Alameda and San Luis Obispo counties during 1880 to 1910) show that local law enforcement was primarily concerned with order maintenance (Dale 1989; Friedman and Percival 1981). The San Luis Obispo police, for example, were "concerned with arresting drunks to the exclusion of almost all other activities." In one year, "except for two arrests for the use of vulgar language and one for doing business without a license, the entire work of the police force, at least as reflected in the arrests they made, was focused exclusively on apprehending drunks" (Dale 1989, 36).

More serious law enforcement was not necessarily left to vigilantes. Vigilantes were undoubtedly responsible for pressure to create a more secure system of state punishment, but they were too insignificant to substitute for it and, at least in the case of the second vigilance committee of San Francisco in 1856, were more concerned with controlling the municipal government (and the spoils of municipal contracts) than controlling crime (Mullen 1989). Vigilantes were not active for much of the period: the last lynching in Los Angeles was in 1874 (Mullen 1989, 11), and there were no recorded lynchings in Sacramento from 1853 to 1900 (Tillman 1986, 170). 
Ultimately, it is difficult to say with much precision whether financial incentives drove prison overcrowding. An empirical analysis of the relationship between county crime rates and prison usage for the period (as in Ball 2012, for example) is impossible, given that there is so little data from the time. There is nothing like the Uniform Crime Reports for nineteenth-century California, as many have observed (Maltz 1977; Boessenecker 1999; Friedman and Percival 1981; McKanna 2002; Muller 1989). We have no official property crime reports. Those who have attempted to measure crime after statehood have typically looked at homicides, since these are usually newsworthy and can therefore be corroborated in the popular press.

McKanna (2002), however, has cautioned that observed criminal justice responses such as indictments are not accurate pictures of crime itself, even for cases of homicide, since "many cases were simply not prosecuted because the population was transient, lawless elements within the society could lynch victims with virtual impunity, or the rough frontier concept of self-defense prevailed" (p. 5). Crime and punishment was also racialized. "There were two standards of justice, one for whites and another for minorities" (p. 2): less than half of whites who were accused of homicide were even indicted (p. 100).

With that said, what can we say about crime patterns in the early years of statehood? Boessenecker (1999) reports that the 1851 homicide rate in Los Angeles was the highest ever reported in the United States $(1,240$ per 100,000) and that the city was much more dangerous in the 1850s than it is today (p. 323). In San Francisco, however, Mullen (1989), using a similar methodology, has argued that much of that city's early reputation for violence was self-serving historicism on the part of the Committee of Vigilance (p. 82). "Either the crimes happened and just did not get into the papers, as suggested by Mary Williams and others, or our perception of life in boomtown San Francisco needs modification" (p. 108).

In sum, what little we do know about crime rates relates to violent crime, but we know almost nothing reliable enough about property crime rates in early statehood to draw statistical inferences, and property offenders were the largest group in the state's prisons. Our evidence for the financial sources of overcrowding will have to come from elsewhere.

\section{Misaligned incentives}

Though there is not enough data to make a statistical case for or against the existence of fiscally driven prison commitments, it is worth noting that there were, at least initially, financial incentives that might have affected the size and shape of California criminal justice. Some practices, like county road gangs, might have made local dispositions cheaper; others, such as reimbursing sheriffs for transporting convicts to prison, might have made prison more attractive; and still others, like capitation fees for reform school, might have made state facilities less attractive. The potential distortions of the latter two arrangements were known to state policy-makers and addressed explicitly by them. Contemporary state officials, at least, were concerned that counties were trying to gain financial advantage through their usage of state institutions. 
The price of local justice. If convict labor were a valuable economic resource, and counties could exploit it, might that have kept the state prison population artificially low? In prior work (Ball 2014b), I explored evidence that county road gangs in the Carolinas did exactly that. California also authorized county road gangs, but there is no evidence that they were employed to a large degree in the first 50 years of statehood. A state statute in 1850 authorized counties to cause "any person ... . under sentence of imprisonment, whether in the State prison or county jail . . . to labor on any public work within the limits of the county" (Hittell 1872,83 ). (In this era of county jail prison, it bears repeating that, in 1850, "state prison" meant a person serving a state sentence in the county jail. There was no state prison, only county jails. Eventually, in the latter part of the nineteenth century, the state, too, had road gangs, but these were limited to a six-mile radius around the prison [Wythe 1909, 100].)

There are scattered reports of profitable county road gangs. In 1905, the El Dorado Sheriff reported that El Dorado work gangs had put in 72 days' work, "which he considers worth at least $\$ 1.20$ per day above cost of keeping and guarding prisoners" (California State Board 1905, 68). Dale (1989, 78-79) also reports that San Luis Obispo used a road gang for hoboes starting in 1907 that was profitable. In 1850s Los Angeles, the county labor force was both privatized and racialized. An 1850 California state law provided that an Indian convicted of a crime could be indentured to a white man who paid for the resulting fines and costs (Woolsey 1979, 83; McKanna 2002, 16-17; Boessenecker 1999, 285). Los Angeles passed its own city ordinance allowing whites to "hire out" Indians "convicted of loitering, assaults, or disturbing the peace. The law stipulated that if the chain gangs became overcrowded, the city could auction off Indians to the highest bidder" (Woolsey 1979, 83, internal citations omitted). Boessenecker (1999) reports that such arrangements often involved the same people "week in and week out, keeping them in involuntary servitude" (p. 285); and Woolsey (1979) offers anecdotal evidence that law enforcement would put Indians in jail "without asking any questions or without knowing the cause" (p. 83, internal citations omitted).

In addition to county convict labor, counties may also have used fines to control populations. After 1857, counties were authorized to substitute monetary fines in lieu of county jail time at the defendant's election (Hittell 1872, 83). (Fines for felonies were also authorized, but Friedman and Percival [1981] found no examples of their being imposed.) A five-day sentence cost $\$ 10$ in Oakland but only $\$ 5$ in San Luis Obispo (Dale 1989, 75-76). Two studies dealing with the period 1880 to 1910 shed some light on the effects of "pay or stay" provisions.

Dale (1989) argues that the lower price set in San Luis Obispo was a form of rationing jail space, since "fully 66 percent [of defendants] were sentenced to pay, or were given the opportunity to pay the fine and chose to do so. Only 34 percent were sent to jail." Dale goes on to explain this in terms of the prevalence of drunkenness cases in San Luis Obispo. A fine would have been preferable to jail time for the defendant, and the court would have also preferred it, since "the small county jail would have burst, and the burden on the taxpayer would have been excessive, if all the drunks sentenced in court were sent to prison" (p. 75). 
Generally, in San Luis Obispo, "county jail was utilized mainly for assault cases and morals cases," while property crimes got prison (pp. 103-4).

Friedman and Percival (1981) observe somewhat similar law enforcement patterns, especially when it comes to the fixation on drunkenness- "at all times the single most common grounds for arrest" (p. 81) - though there were also arrests for other forms of order maintenance, including "brawling, public hell-raising, or ... private disputes that burst into public notice" (p. 75). In the early years of their study, however, most people with the jail/fine choice went to jail. "Between 1879 and 1887, the court actually collected only between 23 percent and 43 percent of the fines and costs imposed." They add, "Unfortunately, we have no way of telling how many people chose jail or fine in the later part of our period" (p. 132).

Fee-based funding and mileage reimbursements. In the early years of statehood, there was no money allocated to salaries for criminal justice officials. Local officials made their living from fees. Justices of the peace in the 1870s, for example, made all their money from fees (Friedman and Percival 1981, 45). Judging was part-time work until 1880 (Friedman and Percival 1981, 47-48). District attorneys were also not employed full time in the 1870s and could practice civil law on the side (Friedman and Percival 1981, 50).

Fee schedules for criminal justice were incredibly detailed, and the fees were established by state statute. Excerpts from one 1857 schedule covering nine counties provided that sheriffs were to be paid a dollar for serving a summons and complaint, 30 cents a mile for traveling in making such services, 50 cents per subpoena to witnesses, 50 cents for bringing up a prisoner on habeas, $\$ 2$ for making every arrest in a criminal proceeding, and $\$ 20$ for an execution (Hittell 1872, 411). Justices of the peace made 50 cents for swearing a jury, a dollar for issuing a search warrant, 25 cents for issuing an execution, $\$ 3$ for all services relating to a criminal action or proceeding, and $\$ 3$ for "judgment by confession" (Hittell $1872,412-13)$. We can see that these fee schedules at least had the potential to distort behavior. Sheriffs might have been more likely to arrest people, and since justices could make as much from a confession as from a trial, they might have been tempted to push the former.

Though we have no evidence that a desire for profit drove the level of criminal justice activity, the issue of mileage fees did arouse suspicion from contemporary policy-makers. The state paid sheriffs a mileage fee-initially a dollar a mile (State of California 1851, 429) — to take prisoners to state facilities. Two authors have suggested that mileage reimbursements encouraged sheriffs to send more people to state prison, and both, oddly, suggested that they did so via false charges of forgery. Wilkins (2005) argues that travel reimbursement "certainly stimulated sheriffs to keep a sharp eye on possible material for transportation bills" and that by looking at prison records he "noticed names of Indians convicted of forgery in the early days, of whom it might be stated with certainty that they were unable to write their own names, not to speak of the names of others" (p. 12). Duffy (1950) suggests that the prisons were packed almost immediately with spuriously charged prisoners. Sheriffs, 
eager to save their jail space . . . began unloading their troublesome prisoners on Estell. Since the sheriffs were allowed to charge one dollar a mile for bringing prisoners, they were also sending along many Mexicans and Indians who were convicted on forgery charges even though they couldn't write their own names. (p. 88)

But the Prison Report of 1858, summarizing admissions from 1851 to 1858 , shows that only 13 inmates out of 1,297 total-just over 1 percent-were sentenced for forgery (Joint Committee on State Prison Affairs 1858, 18).

Even if the mileage fees did not result in a wave of forged forgery charges, California governors noticed reimbursement's potential distorting effects. Governor Johnson (1858) argued that if prisoner transportation were made a county charge, "subject to actual charges incurred," then the mileage costs would decrease (pp. 35-36). Governor Weller (1858a) said that both prisons and prisoner transportation were

an enormous tax upon the people. Whilst the convicts in many of the states are supporting themselves, we are taxed $\$ 120,000$ per annum to provide for them. . . . If you add to this the amount paid for transportation of convicts $(\$ 35,000)$ you will have a sum equal to the whole expenses of some of our sister states, with four times the population. (p. 56)

Mileage fees were, as the above quotation indicates, quite substantial—almost a fifth of total state expenditures on incarceration.

The state lowered its reimbursement rates in 1856 to 50 cents a mile one way (and, for every additional prisoner transported simultaneously, 25 cents per mile) (Hittell 1872, 815). It also addressed its costs by changing the official distances from a county to San Quentin. All counties got closer to the prison. Alameda was fifty miles away from San Quentin in 1854 (State of California 1854) but became twenty miles away in 1858 (Hittell 1872). Los Angeles, San Luis Obispo, and San Diego each got more than a hundred miles closer. Even San Francisco, just fifteen miles away in 1856, crept three miles closer in 1858.

\section{Reform school and county capitation}

A second area where at least some contemporary policy-makers were aware of the effects of financial incentives involved the state reform school. Counties had to pay the state a capitation fee for (almost) every youth committed; some alleged that this drove them to sentence youth to adult prison instead. An 1889 statute provided that counties could elect to send youth convicted of crimes either to reform school or the county jail or penitentiary (Deering and Deering 1889, 561). Children could also be committed by their parents; if so, parents paid the costs if they were able (Deering and Deering 1889, 566-67). In all other cases, "expenses, including the cost of transportation," were to be "borne one half by the county from which such infant is committed, and the remaining one half shall be borne by the state" (p. 568). In 1895, the payment scheme was modified, making the county capitation rate a flat $\$ 132$ per commitment per year (State of California $1895,123)$. 
The Superintendent of the Whittier Reform School suggested that costs were driving commitment decisions-counties were not sending eligible youth to reform schools because of the expense (Whittier 1902, 9). The Whittier Board proposed abolishing this rule, since "in many cases . . . boys are sent to prison to avoid the expense of sending them here." Boys who could benefit from reform school were, instead, "ruined" in prison, "all because the expense in one case is borne entirely by the State and in the other one half by the State and the other half by the County although it all eventually comes out of the same pocket" (Whittier 1902, 9-10).

The Charities Report of 1906 supported this position and argued that some counties were passing their troublemaking youth to other counties rather than paying for reform school. The Report recommended "that in all cases where a boy or girl who is a non-resident of the county is committed to the reform school, the county committing be released from this payment. It will be far cheaper for the State to bear this burden now than a later and larger one in our State prison" (California State Board 1906, 130). The same report quoted Monterey County Probation officer I. Manning King, who stated that San Francisco, Los Angeles, and San Jose let boys run off to save money on reform school costs (California State Board 1906, 137).

\section{Conclusion}

At the dawn of California statehood, there was a haphazard quality to everything related to incarceration, from the way in which the site of the first prison was selected (when the prison ship Waban dropped anchor) to the whiplash-inducing changes in prison administration and labor contracting. Even the notion of a state prison itself was far from certain. In his 1858 farewell address, Governor J. Neely Johnson proposed to get rid of the state prison entirely, reverting to a system where each county jail became "a branch of the state prison" and "each county [would] assume the expense and management of those convicted in their courts" (p. 28). This arrangement would save the state "about one-fourth of the entire expenses of our government" and enable better treatment; counties, meanwhile, could cover their costs with convict labor (p. 28).

The terrible condition of the county jails in the early 1850s had given rise to San Quentin; 50 years later, many jails had failed to improve. A California State Board of Charities Report from 1905 noted that statutes establishing safe jail capacities, the separation of the sentenced and the nonsentenced, the separation of children and adults, and the separation of men and women were "violated in one or more particulars by over one half (33) of the counties of the State" (p. 42). In the Lassen County jail, for example, there was "no fit place for women or children, or in fact for anybody" (p. 68). The Sacramento jail was "both a moral and physical menace to the city," and the authors reported on it "with a feeling of shame" (p. 72). The Charities Board proposed a statute allowing the sheriff "to refuse to receive a prisoner when no provision has been made by the county for 
his confinement in accordance with the law," (p. 43), akin to sheriffs' power today to release prisoners from overcrowded jails.

The Board also proposed a more radical solution: doing away with jail sentences entirely, a suggestion diametrically opposed to those of early governors like Johnson. The Board wrote,

We believe the time is not far distant when all persons convicted of violation of State laws will be considered and treated as State prisoners and confined at labor in State institutions. This would make the county jail solely a place of detention-just what it was primarily intended to be. (California State Board 1905, 44)

There was no consensus on where to house prisoners in the first 50 years of California statehood. Perhaps the lesson to be drawn is that it is a mistake to assume there is ever anything natural or inevitable about a given set of state and local carceral responsibilities. California experimented with a mix of state and local responsibilities and examined (and attempted to address) incentives that engendered overcrowding. From the vantage point of recent history, Realignment may seem like an experiment, but at the dawn of California statehood, it was arguably state prisons that were the experiment-one of many. If the origins of the California prison system are any indication, we should not assume that any given system, including Realignment, is necessarily here to stay or even the start of a trend. It could simply be the pause before the pendulum begins to swing the other way.

\section{References}

Ball, W. David. 2012. Tough on crime (on the state's dime): How violent crime does not drive California counties' incarceration rates—and why it should. Georgia State Law Review 28 (4): 987-1084.

Ball, W. David. 2014a. Defunding state prisons. Criminal Law Bulletin 50 (5): 1060-90.

Ball, W. David. 2014b. Why state prisons? Yale Law and Policy Review 33 (2): 75-117.

Ball, W. David, and Robert Weisberg. 2014. The new normal? Prosecutorial charging in California after public safety realignment. Stanford, CA: Stanford Criminal Justice Center.

Boessenecker, John. 1999. Gold dust and gunsmoke: Tales of gold rush outlaws, gunfighters, lawmen, and vigilantes. New York, NY: Wiley.

Bookspan, Shelley. 1991. A germ of goodness: The California state prison system, 1851-1944. Lincoln, NE: University of Nebraska Press.

Brooks, S. H. 1861. Annual Report of the Controller of State for the year 1860. In Appendix to the Journals of Assembly of the Twelfth Session of the Legislature of the State of California. Sacramento, CA: State Office. Brooks, S.H. 1861. Annual Report of the Controller of State for the year 1860. In Appendix to the Journals of Assembly of the Twelfth Session of the Legislature of the State of California. Sacramento, CA: State Office.

Brown v. Plata, 131 S. Ct. 1910 (2011).

Budd, James H. 1 January 1895. Inaugural address. In Appendix to the journals of the Senate and Assembly of the Thirty-first Session of the Legislature of the State of California, vol. 1. Sacramento, CA: State Office.

Budd, James H. 4 January 1897. First biennial message to the Legislature of the State of California, Thirtysecond Session. Sacramento, CA: State Office.

Burnett, Peter. 6 January 1851. State of the state address. In Journals of the Legislature of the State of California, Second Session. San Jose, CA: State Printer. 
California State Board of Charities and Corrections. 1905. First biennial report. Sacramento, CA: State Office.

California State Board of Charities and Corrections. 1906. Second biennial report. Sacramento, CA: State Office.

Committee on State Prison. 1852. Report. In Journal of the Assembly of the State of California, 1852. San Francisco, CA: State Printer.

Committee on State Prison. 1857. Report. In Appendix to Assembly Journals of the Eighth Session of the Legislature of the State of California. Sacramento, CA: State Printer.

Dale, Lyle A. 1989. Rough justice: Criminal justice in San Luis Obispo County, California, 1880-1910. MA thesis, California State University, Fullerton.

Deering, F. P., and J. H. Deering. 1889. Supplement to Deering's codes and statutes of California, 1889. San Francisco, CA: Bancroft-Whitney Company.

Downey, John G. 1861. Message of 1/7/1861. In Journal of the Senate of the State of California, Twelfth Session. Sacramento, CA: State Printer.

Duffy, Clinton T. 1950. The San Quentin story. Garden City, NY: Doubleday \& Co.

Eaves, Lucile. 1910. A history of California labor organization. Berkeley, CA: The University of California Press.

Enos, John Summerfield. 1887. Second biennial report of the Bureau of Labor Statistics of the State of California. Sacramento, CA: State Office.

Ford, Tirey Lafayette. 1910. California state prisons: Their history, development, and management. San Francisco, CA: Star Press.

Friedman, L. M., and R. V. Percival. 1981. The roots of justice: Crime and punishment in Alameda County, California, 1870-1910. Chapel Hill, NC: University of North Carolina Press.

Hittell, Theodore H. 1872. The general laws of the State of California, from 1850 to 1864, inclusive. San Francisco, CA: A. L. Bancroft and Company.

Irwin, William. 9 December 1875. Inaugural address. In Journal of the Twenty-first Session of the Assembly of the State of California. Sacramento, CA: State Printer.

Johnson, Neely. 8 January 1858. Farewell address. In Journal of the Senate of the State of California, Ninth Session. Sacramento, CA: State Printer.

Joint Committee of the Senate and Assembly. 1872. Report on the state prison. In Appendix to the Journals of Senate and Assembly of the Nineteenth Session of the Legislature of the State of California, vol. III. Sacramento, CA: State Printer.

Joint Committee of the Senate and Assembly. 1874. Report on the state prison, 1873-1874. Sacramento, CA: State Printer.

Joint Committee on State Prison Affairs. 1858. Report. In Appendix to Assembly journals of the Ninth Session of the Legislature of the State of California. Sacramento, CA: State Printer.

Lamott, Kenneth. 1961. Chronicles of San Quentin: The biography of a prison. New York, NY: David McKay.

Langum, David J. 1987. Law and community on the Mexican California frontier: Anglo-American expatriates and the clash of legal traditions, 1821-1846. Norman, OK: University of Oklahoma Press.

Maltz, Michael D. 1977. Crime statistics: A historical perspective. Crime \& Delinquency 23 (1): 32-40.

Markham, H. H. 1893. First biennial message of Governor H.H. Markham to the Legislature of the State of California. Sacramento, CA: State Office.

Markham, H. H. 1895. Second biennial message of Governor H.H. Markham to the Legislature of the State of California. Sacramento, CA: State Office.

McAfee, Ward M. 1987. Tennessee's private prison act of 1986: An historical perspective with special attention to California's experience. Vanderbilt Law Review 40 (4): 851-65.

McAfee, Ward M. 1990. San Quentin: The forgotten issue of California's political history in the 1850's. Southern California Quarterly 72 (3): 235-54.

McKanna, Clare V., Jr. 1985. Ethnics and San Quentin prison registers: A comment on methodology. Journal of Social History 18 (3): 477-82.

McKanna, Clare V., Jr. 1987. The origins of San Quentin, 1851-1880. California History 66 (1): 49-54.

McKanna, Clare V., Jr. 1989. Ethnicity and homicide in California, 1850-1900 [Computer file]. San Diego, CA: San Diego State University (producer), 1989. Ann Arbor, MI: Inter-university Consortium for Political and Social Research (distributor), 1991. 
McKanna, Clare V., Jr. 2002. Race and homicide in nineteenth-century California. Reno, NV: University of Nevada Press.

McLennan, Rebecca M. 2008. The crisis of imprisonment: Protest, politics, and the making of the American penal state, 1776-1941. New York, NY: Cambridge University Press.

Mechanics' State Council. 1874. Memorial in reference to state prison labor. Sacramento, CA: State Printer.

Messinger, Sheldon L., John E. Berecochea, David Rauma, and Richard A. Berk. 1985. The foundations of parole in California. Law \& Society Review 19 (1): 69-106.

Mullen, Kevin J. 1989. Let justice be done: Crime and politics in early San Francisco. Reno, NV: University of Nevada Press.

Pardee, George. 1905. First biennial message of Governor George Pardee. In Appendix to the Journals of the Senate and Assembly of the Thirty-Sixth Session of the Legislature of the State of California. Sacramento, CA: State Office.

Select Committee on the State Prison Contract. 1857. Report. In Appendix to Assembly journals of the Eighth Session of the Legislature of the State of California. Sacramento, CA: State Printer.

Simon, Jonathan. 1993. Poor discipline: Parole and the social control of the underclass, 1890-1990. Chicago, IL: University of Chicago Press.

State Board of Prison Directors. 1880. First annual report. In Appendix to the journals of the Senate and Assembly of the Twenty-fourth Session of the Legislature of the State of California, vol. ii, 1881. Sacramento, CA: State Office.

State Board of Prison Directors. 1882. Third annual report. Sacramento, CA: State Printer.

State Board of Prison Directors. 1892. Thirteenth annual report. Sacramento, CA: State Printer.

State Board of Prison Directors. 1896. Biennial report, 1894/95-1895/96. Sacramento, CA: State Printer.

State of California. 1850. Statutes of California passed at the First Session of the Legislature. San Ramon, CA: State Printer.

State of California. 1851. Statutes of California passed at the Second Session of the Legislature. San Ramon, CA: State Printer.

State of California. 1853. Statutes of California passed at the Fourth Session of the Legislature. San Francisco, CA: State Printer.

State of California. 1854. Statutes of California passed at the Fifth Session of the Legislature. Sacramendo, CA: State Printer.

State of California. 1895. Statutes of California and amendments to the codes passed at the Thirty-first Session of the Legislature. Sacramento, CA: State Office.

Tillman, Robert H. 1986. The prosecution of homicide in Sacramento California, 1853-1900. Southern California Quarterly 68:167.

Tuthill, Franklin. 1866. The history of California. San Francisco, CA: H.H. Bancroft \& Co.

Weller, John. 8 January 1858 (1858a). Inaugural address. In Journal of the Senate of the State of California, Ninth Session. Sacramento, CA: State Printer.

Weller, John. 4 March 1858 (1858b). Letter to the Assembly. In Journal of the Ninth Session of the Assembly of the State of California. Sacramento, CA: State Printer.

Weller, John. 9 January 1860. Message from the Governor. In Journal of the State Assembly, 1860. Sacramento, CA: State Printer.

Whittier State School Board of Trustees. 1902. Biennial report. Sacramento, CA: State Printer.

Wilkins, James Harold. 2005. The evolution of a state prison. In San Quentin: The evolution of a state prison, eds. Bonnie L. Petry and Michael Burgess. Rockville, MD: Borgo Press.

Woolsey, Ronald C. 1979. Crime and punishment: Los Angeles County, 1850-1856. Southern California Quarterly 61 (1): 79-98.

Wythe, Frederick S. 1909. The prison laws of California. Sacramento, CA: Superintendent of State Printing.

Zimring, Frank, and Gordon Hawkins. 1991. The scale of imprisonment. Chicago, IL: University of Chicago Press. 